\title{
PEMBELAJARAN FISIKA MELALUI INKUIRI TERBIMBING DENGAN MENGGUNAKAN MEDIA KIT LISTRIK PAKET DAN SWAKARYA DITINJAU DARI KREATIVITAS DAN KECERDASAN KINESTETIK SISWA
}

\author{
Wahyuni Purnami ${ }^{1}$, Sarwanto $^{2}$, Masykuri $^{3}$ \\ ${ }^{1}$ Program Studi Pendidikan Sains Program Pascasarjana, \\ Universitas Sebelas Maret \\ Surakarta, 57162, Indonesia \\ wpurnami@gmail.com \\ ${ }^{2}$ Dosen Program Studi Pendidikan Sains Pogram Pascasarjana, \\ Universitas Sebelas Maret \\ Surakarta, 57162, Indonesia \\ sar1to@yahoo.com \\ ${ }^{3}$ Dosen Program Studi Pendidikan Sains Program Pascasarjana, \\ Universitas Sebelas Maret \\ Surakarta, 57162, Indonesia \\ mmasykuri@yahoo.com
}

\begin{abstract}
Abstrak
Penelitian ini bertujuan untuk mengetahui perbedaan hasil belajar antara pembelajaran dengan inkuiri terbimbing dengan menggunakan media kit listrik paket dan swakarya, kreativitas, kecerdasan kinestetik, dan interaksinya. Penelitian ini dilaksanakan pada bulan FebruariNovember 2012 dengan menggunakan metode kuasi eksperimen. Populasi penelitian adalah seluruh siswa kelas IX SMPN 5 Klaten, Jawa Tengah. Penentuan sampel menggunakan teknik cluster random sampling, yang terdiri dari kelas IX A dan kelas IX C. Kelas IX A diberi pembelajaran dengan menggunakan kit listrik paket dan kelas IX C menggunakan kit listrik swakarya. Instrumen tes digunakan untuk mengukur data hasil belajar kognitif. Observasi unjuk kerja dan angket digunakan untuk mengukur kreativitas dan kecerdasan kinestetik. Analisis data menggunakan anava tiga jalan dengan desain faktorial $2 \times 2 \times 2$ dan dilanjutkan dengan uji Scheffe. Dari penelitian ini disimpulkan bahwa: 1) ada perbedaan hasil belajar yang signifikan antara siswa yang diberi pembelajaran dengan menggunakan metode inkuiri terbimbing dengan menggunakan media kit listrik paket dan swakarya; 2) ada perbedaan hasil belajar yang signifikan antara siswa yang mempunyai kreativitas tinggi dan rendah; 3) ada perbedaan hasil belajar yang signifikan antara siswa yang mempunyai kecerdasan kinestetik tinggi dan rendah; 4) tidak ada interaksi antara media dan kreativitas terhadap hasil belajar; 5) tidak ada interaksi antara media dan kecerdasan kinestetik terhadap hasil belajar siswa; 6) ada interaksi antara kreativitas dan kecerdasan kinestetik terhadap hasil belajar siswa; 7) tidak ada interaksi antara media, kreativitas, dan kecerdasan kinestetik terhadap hasil belajar siswa.
\end{abstract}

Kata Kunci: Metode inkuiri terbimbing, kit listrik, kreativitas siswa, kecerdasan kinestetik 


\section{Pendahuluan}

Masalah-masalah tantangan global di abad ke-21 banyak dirasakan oleh bangsa Indonesia masa kini, diantaranya pertentangan antar kelompok sosial yang tak terkendali, kesenjangan yang makin besar antara pihak kaya dan miskin, makin meningkatnya tingkat kejahatan dalam masyarakat dan sebagainya. Dalam menghadapi berbagai tantangan global tersebut sangat bergantung pada penggunaan sains dan teknologi secara bijaksana. Kemampuan penggunaan sains dan teknologi ini bergantung pada kedalaman, sebaran dan keefektifan pendidikan yang diterima masyarakat.

Negara yang memprioritaskan pendidikan untuk seluruh lapisan masyarakatnya, akan mempengaruhi pola pikir maupun pola tindak masyarakat tersebut. Pendidikan yang diperlukan adalah pendidikan yang mampu mempersiapkan manusia untuk mengisi kehidupan secara bertanggung jawab (Liliasari, 2011).

Harapan masyarakat terhadap peningkatan kualitas pendidikan di Indonesia semakin besar. Masyarakat berharap adanya kemajuan ilmu pengetahuan dan teknologi yang pesat, akan mampu membentuk karakter peserta didik yang kuat dan kokoh yang diyakini merupakan hal penting dan mutlak dimiliki anak didik untuk menghadapi tantangan hidup masa depan. Namun dalam pelaksanaan pembelajaran di kelas ternyata dihadapkan pada masalah yang menghambat keberhasilan proses pembelajaran. Proses belajar yang berlangsung selama ini, siswa cenderung duduk, diam dan sekedar mendengarkan tanpa memberikan respon yang relevan dengan materi belajar. Kecenderungan ini menjadi kendala bagi pengajar karena menyebabkan ketercapaian penguasaan materi pembelajaran oleh siswa sangat rendah. \begin{tabular}{llr}
\multicolumn{1}{r}{ Telah } & banyak upaya yang \\
dilakukan & pemerintah & untuk \\
meningkatkan & kualitas pendidikan di \\
Indonesia & diantaranya dengan
\end{tabular} mensyahkan Undang Undang Nomor 20 Tahun 2003 tentang Sistem Pendidikan Nasional. Pada pasal 3 Undang Undang tersebut menyatakan bahwa pendidikan bertujuan untuk berkembangnya potensi peserta didik agar menjadi manusia yang beriman dan bertakwa kepada Tuhan Yang Maha Esa, berakhlak mulia, sehat, berilmu, cakap, kreatif, mandiri, dan menjadi warga negara yang demokratis serta bertanggung jawab.

Salah satu prinsip dalam melaksanakan pendidikan adalah siswa secara aktif mengambil bagian dalam kegiatan belajar mengajar. Adanya perkembangan berpikir dengan membuat kerangka pengertian yang baru, siswa harus punya pengalaman antara lain dengan membuat hipotesis, meramalkan, menguji hipotesis, memanipulasi objek, memecahkan persoalan, mencari jawaban, menggambarkan, meneliti, berdialog, mengadakan refleksi, mengungkapkan pertanyaan, mengekspresikan gagasan. Belajar yang sungguh-sungguh akan terjadi bila siswa mengadakan refleksi, pemecahan konflik pengertian, dan selalu memperbaharui tingkat pemikiran yang tidak lengkap (Fosnot, dalam Paul Suparno: 13).

Pada kenyataannya masalahmasalah dalam dunia pendidikan sangat kompleks. Salah satu masalah yang dihadapi dunia pendidikan adalah lemahnya proses pembelajaran. Dalam proses pembelajaran, anak kurang didorong untuk mengembangkan kemampuan berpikir. Proses pembelajaran di dalam kelas selama ini masih diarahkan kepada kemampuan anak untuk menghafal informasi, dipaksa untuk mengingat dan mengumpulkan berbagai informasi tanpa dituntut untuk memahami 2 informasi yang diingatnya. Pendidikan kurang diarahkan untuk membangun 
dan mengembangkan karakter serta potensi yang dimiliki siswa. Dengan kata lain proses pendidikan belum diarahkan untuk membentuk manusia yang cerdas, memiliki kemampuan memecahkan masalah hidup serta belum diarahkan untuk membentuk manusia yang kreatif dan inovatif.

Salah satu ukuran keberhasilan kegiatan proses belajar mengajar dapat dilihat dari perolehan nilai-nilai siswa pada setiap mata pelajaran. Pada pembelajaran IPA sering kali hasil belajar siswa masih rendah, masih banyak siswa yang nilainya di bawah Kriteria Ketuntasan Minimal (KKM). Hasil penelusuran data untuk pembelajaran IPA di SMPN 5 Klaten digunakan data Ujian Nasional sebagai data yang standar selama 2007/2008 sebesar 6,35; 2008/2009 sebesar 6,69; 2009/2010 sebesar 6,22 dan 2010/2011 sebesar 6,57. Hasil nilai IPA pada semester sebelumnya menunjukkan nilai yang belum memuaskah yaitu ratarata sekitar 58,8 persen dari 56 siswa menunjukkan masih di bawah KKM. Pada pokok bahasan listrik dinamis sering kali siswa mengalami kesulitan dalam memahami, menerapkan, menganalisis, dan menemukan konsep kelistrikan.

Apabila dikaitkan dengan makna belajar menurut Suparno (1997: 61) belajar merupakan proses mengkonstruksi arti yang berlangsung secara terus menerus setiap kali berhadapan dengan fenomena atau persoalan yang baru. Bruner menyarankan agar siswa-siswa hendaknya belajar melalui berpartisipasi secara aktif dengan konsep-konsep dan prinsip-prinsip, agar mereka dianjurkan untuk memperoleh pengalaman dan melakukan pengalaman-pengalaman yang memungkinkan mereka untuk menemukan prinsip-prinsip itu sendiri. Menurut Gagne dalam Dahar (2007), belajar merupakan kegiatan yang kompleks. Hasil belajar berupa ranah kognitif, afektif, dan psikomotorik.
Setelah belajar orang memiliki keterampilan, pengetahuan, sikap dan nilai.

Berdasarkan teori-teori belajar tersebut maka perlu metode pembelajaran yang mendukung tercapainya teori belajar tersebut. Salah satu metode pembelajaran di abad 21 ini adalah metode pembelajaran inkuiri. Pembelajaran inkuiri merupakan pembelajaran yang lebih menekankan peran aktif siswa baik fisik maupun mental. Menurut Khan (2011) bahwa ada perbedaan yang signifikan antara siswa yang diberi pembelajaran dengan menggunakan inkuiri dibandingkan dengan menggunakan cara tradisional. Hasil dari penelitian ini menyatakan bahwa pembelajaran dengan inkuiri pada laboratorium meningkatkan pemahaman siswa dalam menemukan pengetahuan dan terampil dalam proses tersebut. Menurut Kuhlthau (2010) metode pembelajaran inkuiri terbimbing merupakan metode yang menjadi jalan dalam mempersiapkan anak-anak usia sekolah dalam abad 21. Menurut Khan (2011) dalam penelitiannya tentang perbandingan antara siswa pada pendidikan menengah yang diberi pembelajaran inkuri dan siswa yang tidak diberi pembelajaran inkuiri, dengan mempertimbangkan faktor kecerdasan, dapat disimpulkan bahwa siswa yang diberi pembelajaran inkuiri secara statistik mempunyai nilai prestasi yang signifikan positif dibandingkan siswa tanpa pembelajaran inkuiri.

Selain metode pengajaran yang tepat, perlu penggunaan media sebagai alat untuk tercapainya pembelajaran yang optimum. Menurut Heinich dkk yang dikutip oleh Arsyad (2007: 4) medium adalah perantara yang mengantar informasi antara sumber dan penerima. Menurut Hamalik dalam Arsyad (2007: 15) mengemukakan bahwa "pemakaian media pembelajaran dalam proses belajar mengajar dapat membangkitkan keinginan dan minat yang baru, membangkitkan motivasi 
dan rangsangan kegiatan belajar". Sudjana \& Rivai (2001: 2) mengemukakan manfaat media pembelajaran dalam proses belajar siswa, yaitu: 1) pembelajaran akan lebih menarik perhatian siswa, 2) bahan pembelajaran akan lebih jelas maknanya, 3) metode mengajar akan lebih bervariasi, 4) siswa dapat lebih banyak melakukan kegiatan belajar. Berdasarkan pentingnya media seperti dikutip di atas maka diteliti pengaruh penggunaan media kit listrik paket dan swakarya siswa. Kit listrik paket terdiri dari peralatan listrik yang telah tertata pada dudukan (tray) yang tertulis sesuai dengan urutan yang tercetak di bagian dalam penutup kotak buatan pabrik. Masing-masing komponen ditempatkan pada denah dengan diberi nama dan gambar teknis supaya mudah dan cepat mengetahui tata letak komponen bila memerlukan maupun menata kembali. Kit listrik swakarya merupakan rangkaian listrik hasil rangkaian manual dari siswa. Menurut Kerucut Pengalaman Dale, penggunaan media kit listrik ini menempati posisi paling bawah yaitu kelompok pengalaman konkret (enactif experient).

Anak yang kreatif selalu ingin tahu, memiliki minat yang luas, dan menyukai kegemaran dan aktivitas yang kreatif, serta berani mengambil resiko (tetapi dengan perhitungan). Rasa percaya diri, keuletan, dan ketekunan membuat mereka tidak cepat putus asa dalam mencapai tujuan mereka. Ciri kreatif lainnya ialah kecenderungan untuk lebih tertarik pada hal-hal rumit dan misterius. Munandar (2009) melakukan penelitian kreativitas dengan membandingkan pendapat tiga kelompok, yaitu kelompok psikolog, guru dan orang tua. Dari penelitian ini ditemukan perbedaan kelompok orang yang sangat kreatif dan kelompok orang yang kurang kreatif.

Selain kreativitas, salah satu hal yang perlu diperhatikan dalam mendukung pembelajaran yang optimal yaitu kecerdasan kinestetik. Menurut
Gardner (2003), kecerdasan pada siswa itu komplek yang dikenal dengan Multiple Intellegency atau kecerdasan majemuk. Kecerdasan kinestetik merupakan salah satu dari kecerdasan majemuk tersebut yang sering dikenal dengan kecerdasan gerak. Sedangkan karakteristik anak yang mempunyai kecerdasan kinestetik diantaranya lebih cepat menerima informasi jika mereka terlibat dalam kegiatan, kegiatan yang menarik perhatian atau menggunakan seluruh tubuh untuk mengekspresikan diri, mereka senang dengan gerakan fisik dan tidak bisa diam dalam waktu lama. Kemampuan memahami intelegensi anak akan membantu proses pembelajaran yang optimum karena setiap anak memiliki kemampuan belajar yang berbeda-beda tergantung pada intelegensi yang paling menonjol pada dirinya

Berdasarkan latar belakang masalah dan kajian pustaka di atas, maka dilakukan penelitian pembelajaran fisika dengan tujuan untuk mengetahui perbedaan hasil belajar antara pembelajaran melalui inkuiri terbimbing dengan menggunakan media kit listrik paket dan swakarya, perbedaan hasil belajar pada siswa kreativitas tinggi dan rendah, perbedaan hasil belajar pada siswa kecerdasan kinestetik tinggi dan rendah dalam pembelajaran fisika dan interaksinya.

\section{Metode Penelitian}

Penelitian dilaksanakan di SMPN 5 Klaten, Jawa Tengah dimulai dari bulan Februari-November tahun 2012. Penelitian ini termasuk penelitian eksperimen. Kelompok eksperimen I akan diajar dengan metode inkuiri terbimbing melalui media kit listrik paket dan kelompok eksperimen II dengan menggunakan metode inkuiri terbimbing melalui media kit listrik swakarya, yang sebelum perlakuan dilakukan uji coba instrumen guna mengetahui validitas (menggunakan pertimbangan ahli/expert judgement), 
reliabilitas, uji daya beda dan tingkat kesukaran soal.

Rancangan penelitian ini disusun sesuai dengan variabel-variabel yang terlibat. Variabel-variabel terlibat dalam penelitian ini merupakan cerminan dari data-data yang diperoleh setelah perlakuan terhadap sampel penelitian dilakukan. Data yang diperoleh kemudian dianalisis menggunakan uji anava tiga jalan $2 \times 2 \times 2$. Teknik pengambilan sampel yang digunakan dalam penelitian ini adalah teknik cluster random sampling, yaitu kelas IX A diberi pembelajaran dengan metode inkuiri terbimbing melalui media kit listrik paket dan kelas IXC diberi pembelajaran dengan metode inkuiri terbimbing melalui media kit listrik swakarya.

Teknik pengumpulan data dalam penelitian ini menggunakan angket, observasi dan tes prestasi belajar. Angket yang digunakan adalah angket untuk mengukur kreativitas, kecerdasan kinestetik, kemampuan afektif. Observasi dilakukan untuk observasi unjuk kerja kreativitas, psikomotorik dan afektif. Tes digunakan untuk mengukur hasil belajar. Implementasi perlakuan inkuiri terbimbing dilaksanakan melalui pedoman perangkat pembelajaran yang terdiri dari: 1) silabus, 2) Rencana Pelaksanaan Pembelajaran (RPP), 3) Lembar Kerja Siswa (LKS).

Uji normalitas dan homogenitas data yang digunakan adalah uji Kolmogorov Smirnov dan uji Levene. Pengujian hipotesis pada penelitian ini menggunakan anava tiga jalan $2 \times 2 \times 2$.

\section{Hasil dan Pembahasan}

Tabel 1 menyajikan deskripsi data hasil belajar aspek kognitif, afektif dan psikomotorik pada penggunaan media kit listrik, kreativitas, kecerdasan kinestetik, dan interaksinya.

Tabel 1. Deskripsi Data Interaksi Media, Kreativitas,

\begin{tabular}{llll}
\multicolumn{3}{c}{ dan } & Kecerdasan Kinestetik \\
\hline Media & $\begin{array}{l}\text { Kreati } \\
\text { vitas }\end{array}$ & $\begin{array}{l}\text { Kecer } \\
\text { dasan }\end{array}$ & Mean \\
& & & \\
\hline
\end{tabular}

\begin{tabular}{|c|c|c|c|c|c|}
\hline & & $\begin{array}{l}\text { kines } \\
\text { tetik }\end{array}$ & & & \\
\hline $\begin{array}{l}\text { Kit } \\
\text { Listrik }\end{array}$ & & & $\begin{array}{l}\text { Kogni } \\
\text { tif }\end{array}$ & Afektif & $\begin{array}{l}\text { Psiko } \\
\text { motorik }\end{array}$ \\
\hline \multirow[t]{4}{*}{ Paket } & Rendah & Rendah & 64,83 & 65,00 & 61,83 \\
\hline & & Tinggi & 66,87 & 61,00 & 78,35 \\
\hline & Tinggi & Rendah & 65,00 & 64,20 & 70,40 \\
\hline & & Tinggi & 83,88 & 83,66 & 79,00 \\
\hline \multirow{4}{*}{$\begin{array}{l}\text { Swakar } \\
\text { ya }\end{array}$} & Rendah & Rendah & 73,37 & 66,87 & 76,62 \\
\hline & & Tinggi & 76,60 & 72,40 & 73,00 \\
\hline & Tinggi & Rendah & 73,60 & 84,10 & 77,40 \\
\hline & & Tinggi & 85,20 & 87,60 & 89,80 \\
\hline
\end{tabular}

Berdasarkan hasil uji normalitas dan homogenitas maka diperoleh data terdistribusi normal dan homogen. Data hasil uji anava pada aspek kognitif, afektif, dan psikomotorik disajikan pada Tabel 2

\begin{tabular}{|c|c|c|c|}
\hline Materi & Kognitif & afektif & $\begin{array}{c}\text { Psikomot } \\
\text { orik }\end{array}$ \\
\hline $\begin{array}{l}\text { Kit listrik } \\
\text { paket dan } \\
\text { swakarya }\end{array}$ & 0,01 & 0,00 & 0,03 \\
\hline Kreativitas & 0,01 & 0,00 & 0,02 \\
\hline $\begin{array}{l}\text { Kecerdasan } \\
\text { Kinestetik }\end{array}$ & 0,01 & 0,01 & 0,01 \\
\hline $\begin{array}{l}\text { Media } \\
\text { *kreativitas }\end{array}$ & 0,41 & 0,29 & 0,41 \\
\hline $\begin{array}{l}\text { Media } \\
{ }^{*} \text { kecerdasan } \\
\text { Kinestetik }\end{array}$ & 0,55 & 0,47 & 0,12 \\
\hline $\begin{array}{l}\text { Kreativitas } \\
\text { *kecerdasan } \\
\text { Kinestetik }\end{array}$ & 0,02 & 0,02 & 0,39 \\
\hline $\begin{array}{l}\text { Media* } \\
\text { kreativitas } \\
\text { *kecerdasan } \\
\text { Kinestetik }\end{array}$ & 0,41 & 0,01 & 0,03 \\
\hline
\end{tabular}

1. Perbedaan hasil belajar antara siswa yang memperoleh pembelajaran dengan metode inkuiri terbimbing melalui media kit listrik paket dan swakarya

Hasil analisis data hasil belajar kognitif menunjukkan signifikansi sebesar 0,01. Hal ini berarti ada perbedaan yang signifikan antara siswa yang diberi pembelajaran inkuiri 
terbimbing melalui media kit listrik paket dengan siswa yang diberi pembelajaran inkuiri terbimbing menggunakan media swakarya.

Siswa yang diberi pembelajaran dengan metode inkuiri terbimbing melalui media kit listrik paket mempunyai nilai rata-rata 71,57 sedangkan siswa yang diberi pembelajaran dengan media swakarya mempunyai nilai rata-rata 76,14 . Hal ini dapat dijelaskan bahwa pembelajaran dengan inkuiri terbimbing merupakan pembelajaran yang melibatkan siswa secara langsung dalam penemuan konsep yang dibimbing melalui pertanyaan-pertanyaan. Pembelajaran inkuiri terbimbing melalui media swakarya dengan menggunakan rangkaian sendiri justru melatih siswa untuk belajar dari hal-hal yang sederhana yang berhubungan langsung dengan kehidupan sehari-hari dan pengalaman baru yang membentuk konsep dalan diri siswa. Sesuai dengan penelitian Anderson (2002), yang menyimpulkan pembelajaran dengan metode inkuiri akan meningkatkan hasil belajar. Belajar dari pengalaman merupakan pola pembelajaran yang juga sesuai teori Bruner yang menyatakan bahwa pembelajaran dengan penemuan (discovery) membuat siswa akan memiliki pengetahuan yang bertahan lama dalam ingatan bila dibandingkan dengan pengetahuan yang diperoleh dengan cara-cara yang lain. Hasil belajar penemuan mempunyai efek transfer yang lebih baik. Konsepkonsep dan prinsip-prinsip yang dimiliki seseorang akan mudah diterapkan pada situasi-situasi yang baru, meningkatkan penalaran siswa dan kemampuan untuk berpikir bebas, dan juga dapat melatih ketrampilan kognitif siswa menemukan dan memecahkan masalah tanpa pertolongan orang lain, membangkitkan keingintahuan siswa, memberi motivasi untuk bekerja terus sampai menemukan jawaban-jawaban dan siswa mampu menganalisa serta memanipulasi informasi.

Sesuai dengan kerucut pengalaman Dale, maka penggunaan media kit listrik ini menempati urutan bawah yaitu kategori enaktif atau pengalaman konkrit, siswa melalui gerak dan memanipulasi materi secara langsung dalam proses belajarnya.

Hasil penelitian mengenai penggunaan media kit listrik paket dan swakarya dalam pembelajaaran ini sesuai dengan dasar teori dari Gagne dalam Arsyad (2007: 4) yang menyatakan bahwa media merupakan alat yang secara fisik digunakan untuk menyajikan isi materi, sehingga media merupakan alat bantu untuk mempermudah penyampaian informasi, menarik serta memberi pengalaman baru bagi siswa sehingga memungkinkan siswa memahami isi materi secara lebih mendalam. Hasil penelitian ini juga sesuai dengan penelitian yang telah dilakukan Basuki (2012) dan Tarno (2010) yang menyimpulkan bahwa penggunaan media berpengaruh terhadap hasil pembelajaran.

Penggunaan media kit listrik paket dan swakarya ini juga mempunyai pengaruh terhadap hasil belajar afektif dan psikomotorik. Hasil belajar siswa yang menggunakan pembelajaran dengan rangkaian swakarya memiliki rata-rata hasil belajar yang lebih tinggi dibandingkan dengan menggunakan kit listrik paket. Hal ini menunjukkan bahwa media swakarya mempunyai pengaruh yang lebih besar terhadap hasil belajar afektif dan psikomotorik.

Oleh karena itu, penggunaan media dalam pembelajaran dengan menggunakan kit listrik swakarya siswa ini sangat mendukung pada sekolah yang tidak tersedia kit listrik pendukung seperti kit listrik paket. Ketersediaan kit listrik yang sederhana seperti rangkaian kit listrik swakarya siswa, justru membangun siswa untuk 
menemukan suatu konsep sendiri dengan baik.

Seperti di SMPN 5 Klaten yang tidak tersedia kit listrik paket, berdasarkan penelitian ini, pemakaian rangkaian kit listrik swakarya ternyata justru memberi pengalaman yang lebih baik dari pada pemakaian kit listrik paket. Begitu juga untuk sekolahsekolah yang tidak mempunyai kit listrik paket dapat meningkatkan hasil belajar kognitif, afektif, dan psikomotorik pada materi pembelajaran listrik dinamis dengan menggunakan media rangkaian swakarya siswa.

2. Perbedaan hasil belajar antara siswa yang mempunyai kreativitas tinggi dan rendah

Berdasarkan hipotesis 2 tentang perbedaan antara kreativitas tinggi dan rendah terhadap hasil belajar, diperoleh Signifikansi $0,01<0,05$. Berarti ada perbedaan hasil belajar antara siswa yang mempunyai kreativitas tinggi dan siswa yang mempunyai kreativitas rendah. Rata-rata nilai pada siswa yang kreativitas tinggi sebesar 77,08 sedangkan rata-rata nilai siswa yang kreativitas rendah sebesar 70,18.

Data statistik diatas diketahui bahwa siswa yang mempunyai kreativitas tinggi akan memperoleh rata-rata hasil belajar lebih tinggi dari pada siswa yang kreativitasnya rendah. Pembelajaran IPA dengan inkuiri terbimbing melatih siswa untuk mampu merumuskan masalah, menentukan hipotesis, mengumpulkan data, menguji hipotesis dan menyimpulkan hasilnya. Pembelajaran tersebut akan mendukung perkembangan kreativitas, anak diberi kesempatan untuk mengembangkan kreativitasnya dengan cara anak menyalakan lampu dengan berbagai cara, anak tertantang untuk menemukan sebanyak-banyaknya cara untuk menyalakan bola lampu sehingga kemampuan kreatifnya berkembang. Hal yang penting dalam mendukung kreativitas menurut Piaget dalam Dahar (1989: 162) adalah perumusan pertanyaan-pertanyaan, karena perumusan pertanyaan merupakan bagian paling penting dan paling kreatif dari sains yang diabaikan dalam pendidikan sains. Suatu bagian penting dari konstruksi pertanyaan-pertanyaan tersebut adalah selain para siswa mencoba menjawab pertanyaanpertanyaan atau memecahkan masalah-masalah, siswa juga termotivasi untuk bekerja keras. Metode pembelajaran yang tepat dapat merangsang siswa untuk dapat tertarik dan mudah menjawab pertanyaan-pertanyaan tersebut. Menurut Munandar (2009) bahwa anak yang mempunyai kreativitas tinggi senantiasa memiliki rasa ingin tahu yang tinggi, tertantang oleh kemajemukan dan tidak mudah menyerah dalam menghadapi masalah. Hasil penelitian tentang kreativitas ini juga sesuai dengan pembelajaran sains yang berkarakter, menurut Widha (2011) pembelajaran sains harus dikemas dalam pembelajaran aktif, inovatif, kreatif, efektif dan menyenangkan serta gembira dan berbobot. Hasil penelitian di atas juga sesuai dengan penelitian yang dilakukan Tarno (2010) dan Srining (2010) yang menyimpulkan bahwa kreativitas mempunyai pengaruh terhadap nilai hasil belajar.

Kemampuan anak dalam merangkai, mengamati, mengubah kedudukan benda dan lain-lain semua memerlukan ketrampilan psikomotorik, maka anak yang kreativitasnya tinggi akan mempunyai hasil belajar psikomotorik yang tinggi pula. Pengaruh kreativitas siswa terhadap hasil belajar ini juga sesuai dengan penelitian yang telah dilakukan oleh Oktaffi (2012) dan Fuadi (2007) menyimpulkan dalam penelitiannya bahwa terdapat pengaruh yang signifikan pada kreativitas siswa terhadap hasil belajar ranah kognitif, afektif maupun psikomotorik. Oleh karena itu, kondisi yang mendukung untuk perkembangan kreativitas anak di 
sekolah mestinya senantiasa diperhatikan dalam proses pembelajaran. Sesuai dengan latar belakang masalah di lapangan masih seringnya pembelajaran yang berpusat pada guru, maka dengan adanya hasil penelitian tentang pengaruh kreativitas ini perlu ditinjau kembali cara pembelajaran yang selama ini dilakukan, untuk lebih menekankan pada pembelajaran yang mendukung kreativitas anak dan memberi pengalaman belajar pada anak, sehingga kreativitas anak akan dapat tumbuh berkembang dengan baik. Salah satu usaha yang dapat dilakukan dalam pengembangan kreativitas anak adalah pembelajaran yang interaktif melalui eksperimen sehingga anak ikut aktif dalam proses pembelajaran.

3. Perbedaan hasil belajar antara siswa yang mempunyai kecerdasan kinestetik tinggi dan rendah

Berdasarkan hasil uji hipotesis 3 diperoleh signifikansi $0,01<0,05$ maka ada perbedaan antara siswa yang mempunyai kecerdasan kinestetik tinggi dan rendah terhadap hasil belajar baik kognitif. Sesuai dengan penelitian yang telah dilakukan oleh Rahman dan Suyata (2004), yang menyimpulkan bahwa metode inteligensi ganda lebih efektif daripada metode tradisional terhadap hasil belajar fisika, bahwa kecerdasan kinestetik yang merupakan bagian dari intelegensi ganda juga mampu meningkatkan hasil belajar siswa. Hal ini disebabkan metode pembelajaran inkuiri dengan menggunakan eksperimen akan sesuai dengan anak-anak yang mempunyai kecerdasan kinetetik tinggi, karena pada pembelajan tersebut siswa akan aktif menggerakkan seluruh anggota tubuh untuk ikut dalam proses pembelajaran, misalnya pengalaman memegang dan menggunakan alat ukur arus listrik merupakan pengalaman belajar yang akan tertanam dalam diri anak.

Keaktifan dan keterlibatan dalam gerakan tubuh pada proses pembelajaran inkuiri terbimbing melalui eksperimen ini juga sesuai dengan penelitian yang telah dilakukan Khan dan Iqbal (2011) yang menyimpulkan bahwa pembelajaran dengan metode inkuiri sebagai eksperimen mempunyai nilai yang signifikan apabila dibandingkan kelas kontrol. Pada penelitian Kuhlthau (2010) juga menyimpulkan bahwa untuk mempersiapkan siswa yang handal pada abad 21 perlu pemantapan dalam pembelajaran yaitu dengan menggunakan inkuiri terbimbing. Oleh karena itu pembelajaran dengan metode inkuiri terbimbing dengan melibatkan kecerdasan kinestetik dari siswa perlu diperhatikan oleh guru. Dukungan dan kemampuan untuk menumbuhkan kecerdasan kinestetik siswa perlu diperhatikan baik oleh guru maupun lingkungan belajar siswa, sehingga akan terbentuk generasi siswa yang mampu menghadapi tantangan jaman dan selalu berkembang.

4. Interaksi antara media kit listrik paket dan swakarya terhadap hasil belajar siswa

Hasil rata-rata siswa yang menggunakan kit listrik dan memiliki kreativitas rendah sebesar 65,85 dan kreativitas tinggi dengan rata-rata 74,91 sedangkan hasil rata-rata kelompok yang menggunakan kit listrik swakarya dan memiliki kreativitas rendah sebesar 74,48 dan kreativitas tinggi dengan rata-rata 79,9. Hal ini menunjukkan pembelajaran dengan menggunakan media kit listrik paket maupun media swakarya tidak menunjukkan efek atau kaitan terhadap kelompok kreativitas.

Tidak ada interaksi antara pembelajaran inkuiri terbimbing melalui media dengan kreativitas ini juga terjadi pada hasil belajar afektif maupun psikomotorik. Kondisi ini memang tidak sesuai dengan hipotesis yang di harapkan. Salah satu faktor yang menyebabkan tidak sesuainya hasil statistik dengan hipotesis harapan karena baik siswa yang memiliki kreativitas tinggi maupun rendah belum 
terampil dalam menggunakan kit listrik. Sehingga penggunaan media kit listrik paket dan swakarya tidak mempunyai effek terhadap nilai hasil belajar pada kelompok siswa yang mempunyai kreativitas tinggi dan rendah. Faktor lain yang menyebabkan kondisi ini karena belum terbiasanya siswa mendapatkan pembelajaran dengan menggunakan metode pembelajaran inkuiri terbimbing melalui media kit, namun demikian hasil penelitian sebelumnya yang dilakukan oleh Basuki (2012) dan Sukardi (2012) juga menyimpulkan tidak adanya interaksi antara penggunaan media, kreativitas, dan gaya belajar terhadap hasil belajar. Hal ini disebabkan karena banyak faktor intern dan ekstern pada siswa yang tidak diteliti tetapi berpengaruh terhadap hasil belajar siswa.

Dari hasil uji hipotesis ini meskipun tidak ada interaksi antara kreativitas dengan penggunaan media, namun dapat diketahui bahwa pada kreativitas yang tinggi maupun rendah, penggunaan media swakarya mempunyai pengaruh yang tinggi terhadap hasil belajar, hal ini bisa menjadi acuan bagi para guru di sekolah-sekolah yang tidak tersedia kit listrik paket maka pemakaian kit swakarya siswa justru mendukung pengalaman belajar untuk meningkatkan hasil belajar.

5. Interaksi antara media kit listrik dan swakarya dengan kecerdasan kinestetik terhadap hasil belajar siswa

Nilai rata-rata siswa yang dikenai media kit listrik paket pada kelompok siswa yang memiliki kecerdasan kinestetik rendah sebesar 64,91 dan kelompok siswa yang memiliki kecerdasan kinestetik tinggi sebesar 75.41; sedangkan rata-rata siswa yang dikenai media swakarya pada kelompok kecerdasan kinestetik rendah sebesar 73,48 dan kelompok kecerdasan kinestetik tinggi sebesar 80,90. Hasil deskripsi statistik di atas menunjukkan bahwa penggunaan media swakarya tampaknya sama-sama meningkatkan hasil belajar baik pada siswa yang memiliki kecerdasan kinestetik tinggi maupun rendah. Siswa yang mempunyai kecerdasan kinestetik tinggi memperoleh hasil belajar yang lebih tinggi pada penggunaan media swakarya, tetapi siswa dengan kecerdasan kinestetik rendah juga terangkat hasil belajarnya ketika mereka mengikuti pembelajaran dengan metode inkuiri terbimbing melalui media swakarya. Tidak ada interaksi antara media dengan kecerdasan kinestetik ini juga terdapat pada hasil belajar afektif dan psikomotorik.

Hasil statistik di atas memang tidak sesuai dengan hipotesis yang diharapkan. Faktor yang mungkin mempengaruhi tidak adanya interaksi antara media dan kecerdasan kinestetik adalah penggunaan media kit listrik swakarya memang sudah biasa dilakukan ataupun dilihat oleh siswa dalam kehidupan sehari-hari dari pada penggunaan media kit listrik paket, sehingga nilai hasil belajar pada kelompok yang menggunakan kit listrik swakaya lebih tinggi dari pada media kit listrik paket baik pada kelompok siswa yang mempunyai kecerdasan kinestetik tinggi maupun rendah. Faktor lain yang menyebabkan tidak adanya interaksi karena baik pada penggunaan media kit listrik paket maupun pada kit listrik swakarya sama-sama membutuhkan kecerdasan kinestetik dalam kegiatan merangkai rangkaian listrik. Meskipun kecerdasan kinestetik ini tidak berinteraksi dengan penggunaan media tetapi kecerdasan kinestetik siswa tetap perlu ditumbuh dan diperhatikan dalam proses pembelajaran.

6. Interaksi antara kreativitas dan kecerdasan kinestetik terhadap hasil belajar siswa

Hasil uji statistik menunjukkan ada keterkaitan pada siswa yang mempunyai kreativitas tinggi dan kecerdasan kinestetik tinggi, mempunyai hasil belajar yang tinggi. 
Pada kelompok kreativitas tinggi tetapi kecerdasan kinestetik rendah tidak memiliki nilai hasil belajar yang tinggi. Hal ini menunjukkan siswa yang mempunyai kreativitas tinggi dan didukung kecerdasan kinestetik tinggi akan mampu meningkatkan hasil belajar.

Hasil penelitian ini sesuai dengan penelitian yang dilakukan oleh Sukardi (2012) yang menyimpulkan bahwa ada interaksi antara kreativitas dengan gaya belajar kinestetik baik pada hasil belajar kognitif, afektif maupun psikomotorik. Adanya interaksi antara kreativitas dan kecerdasan kinestetik ini ditunjukkan bahwa kreativitas yang tinggi mempunyai effek yang besar pada kecerdasan kinestetik yang tinggi dengan nilai ratarata hasil belajar yang tinggi, sedangkan kreativitas tinggi maupun rendah tidak mempunyai effek yang besar terhadap kecerdasan kinestetik rendah. Oleh karena itu kedua grafik hubungan antara kreativitas dan kecerdasan kinestetik terhadap hasil belajar akan dapat berpotongan.

7. Interaksi antara media, kreativitas dan kecerdasan kinestetik terhadap hasil belajar siswa

Tidak adanya interaksi ini dapat dijelaskan bahwa pada penggunaan media swakarya baik kreativitas tinggi maupun kecerdasan kinestetik tinggi memiliki nilai hasil belajar kognitif yang tinggi, sedangkan kelompok yang mempunyai kreativitas rendah dan kecerdasan kinestetik rendah juga terangkat nilai hasil belajarnya pada media swakarya. Hasil penelitian ini juga sesuai dengan penelitian yang dilakukan Sukardi (2012) yang menyimpulkan bahwa tidak ada interaksi antara media, kreativitas dan gaya belajar terhadap hasil belajar siswa.

Uji hipotesis 7 pada ranah afektif dan psikomotorik menunjuk ada interaksi antara media, kreativitas dan kecerdasan kinestetik. Setelah dilakukan uji lanjut maka diketahui pada ranah afektif terjadi interaksi antara media kit dengan kreativitas tinggi dan kecerdasan kinestetik (tinggi dan rendah). Keterkaitan antara media, kreativitas dan kecerdasan kinestetik ini menunjukkan pemakaian media yang tepat didukung dengan kreativitas dan kecerdasan kinestetik yang tinggi akan mampu memberikan pengalaman pembelajaran yang dapat meningkatkan hasil belajar siswa.

\section{Kesimpulan dan Rekomendasi}

Berdasarkan hasil penelitian ini dapat disimpulkan sebagai berikut: 1) ada perbedaan terhadap hasil belajar yang signifikan antara siswa yang diberi pembelajaran inkuiri terbimbing melalui media kit listrik paket dan swakarya; 2) ada perbedaan yang signifikan antara kreativitas tinggi dan rendah terhadap hasil belajar siswa; 3) ada perbedaan yang signifikan antara tingkat kecerdasan kinestetik tinggi dan rendah terhadap hasil belajar; 4) tidak ada interaksi antara media dan kreativitas terhadap hasil belajar; 5) tidak ada interaksi antara media dan kecerdasan kinestetik terhadap hasil belajar siswa; 6) ada interaksi antara kreativitas dan kecerdasan kinestetik terhadap hasil belajar siswa; 7) tidak ada interaksi antara media, kreativitas dan kecerdasan kinestetik terhadap hasil belajar siswa.

Pada pembelajaran fisika disarankan untuk melibatkan siswa secara aktif dalam proses pembelajaran dengan memperhatikan faktor internal siswa diantaranya kreativitas dan kecerdasan kinestetik. Pembelajaran fisika dengan menggunakan media kit listrik paket dan swakarya siswa akan meningkatkan hasil belajar siswa, oleh karena itu dalam menggunakan media kit listrik paket dan swakarya, perlu mempersiapkan alat dan LKS sebelum digunakan dalam pembelajaran sehingga pembelajaran dapat berjalan dengan lancar sesuai dengan rencana. 
Dalam penelitian ini kreativitas dan kecerdasan kinestetik siswa dapat meningkatkan hasil belajar baik kognitif, afektif dan psikomotorik. Oleh karena itu guru perlu memperhatikan dan menumbuhkan faktor internal siswa tersebut dengan memberi kesempatan siswa untuk ikut aktif dalam pembelajaran.

Hasil penelitian ini dapat digunakan sebagai acuan untuk mengembangkan penelitian yang sejenis, terutama penelitian fisika yang menekankan pada keikutsertaan siswa dalam proses pembelajaran. Penelitian dapat dikembangkan dengan menggunakan variabel moderator yang lainnya seperti ketrampilan menggunakan alat, kemampuan berpikir kritis, dan sikap ilmiah. Untuk instrumen pengukuran lebih mengembangkannya, terutama pada pengukuran kecerdasan kinestetik dapat dilakukan dengan unjuk kerja dan menggunakan angket.

\section{Daftar Pustaka}

Anderson, R.D. (2002). Reforming Science Teaching: What Research says abaout Inquiry, Journal of Science Teacher Education, 13 (1):1-12, University of Colorado, Boulder, Colorado, 80309, U.S.A.

Arsyad, A. (2005). Media Pembelajaran. Yogyakarta: Pustaka Teknologi

Basuki. (2012). Pembelajaran Fisika Dengan Metode Eksperimen Menggunakan Media Kit IPA dan Animasi Ditinjau dari Kreativitas dan Gaya Belajar. Tesis di Universitas Sebelas Maret Surakarta.

Dahar, R.W. (1989). Teori-teori Belajar. Jakarta : Erlangga

Fuadi, M.A. (2007). Pengaruh Pendekatan Keterampilan Proses Sains Melalui Eksperimen Menggunakan Kit dan Alat Sederhana Pada Pembelajaran Fisika Ditinjau dari Kreativitas siswa. Tesis di Universitas Sebelas Maret.

Gardner, H. (2003). Kecerdasan majemuk: Teori dalam praktik (Terjemahan Alexander Sindoro) Jakarta: Inter aksara. Buku asli diterbitkan tahun 1993

Khan, M. dan Iqbal, M.Z. (2011). Effect of Inquiry Lab Teaching Method on the Development of Scientific Skills Through the Teaching of Biology in Pakistan. Language in India, vol. 11. No. 1.

Khan, S. (2011). Effect of Inquiry Method on Achievement of Students in Chemistry at Secondary Level, International Journal of Academic Research, Vol. 3. No. 1. Part III

Kuhlthau, C. (2010). Guided Inquiry: School Libraries in the $21^{\text {st }}$ Century, School Libraries Worldwide, volume 16, Number 1, $17-28$

Liliasari. (2011). Berpikir Sains Dalam Pembelajaran Untuk Membentuk Manusia Indonesia Yang Kritis, Kreatif dan Berkarakter. Makalah disajikan pada Seminar Nasional Pendidikan Sains Universitas Sebelas Maret: November 2011.

Munandar, U. (2009). Pengembangan Kreativitas Anak Berbakat. Jakarta: Rineka cipta

Oktaffi. (2012). Pembelajaran IPA Melalui Metode Inkuiri Terbimbing dan Proyek Ditinjau dari Kreativitas dan Kemampuan Menggunakan Alat Laboratorium. Tesis di Universitas Sebelas Maret.

Rahman dan Suyata. (2004). Effektivitas Penggunaan Metode Inteligensi Ganda Dalam Proses Pembelajaran Fisika di SMU, Jurnal Penelitian dan Evaluasi, Nomor 7, Tahun VI.

Srining. (2010). Pembelajaran IPA Berbasis Masalah melalui Inkuiri Terbimbing dan Inkuiri Bebas Termodifikasi Ditinjau dari Sikap Ilmiah dan Kreativitas. Tesis di Universitas Sebelas Maret.

Sukardi. (2012). Pembelajaran Berbasis Masalah Melalui Eksperimen dengan Laboratorium Riil dan Laboratorium Virtuil Ditinjau dari Kreativitas dan Gaya Belajar. Tesis di Universitas Sebelas Maret.

Sudjana, N dan Rivai, A. (2002) Media Pengajaran. Bandung: Sinar Baru Algensindo. 
JURNAL INKUIRI

ISSN: 2252-7893, Vol 2, No 12013 (hal 43-56)

http://jurnal.fkip.uns.ac.id/index.php/sains

Suparno, P. (2006). Metodologi

Pembelajaran Fisika

Konstruktivistik dan

menyenangkan. Yogyakarta:

Universitas Sanata Darma

Tarno. (2010) Pembelajaran Fisika dengan Metode Eksperimen Menggunakan Laboratorium Real dan Virtuil Ditinjau dari Kemampuan Berpikir dan Kreativitas Siswa. Tesis di Universitas Sebelas Maret.

Widha, S. (2011). Modul Metodologi Penelitian Pendidikan Sains. Surakarta. 